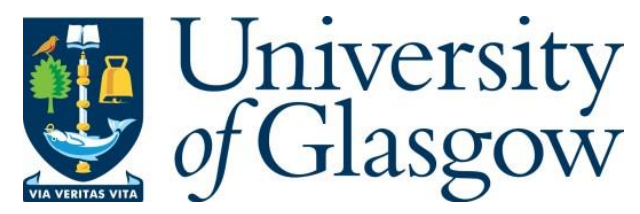

Knight, C. (2006) The metaphysical case for luck egalitarianism. Social Theory and Practice, 32(2), pp. 173-188.

There may be differences between this version and the published version. You are advised to consult the publisher's version if you wish to cite from it.

http://eprints.gla.ac.uk/25834/

Deposited on: 14 July 2021

Enlighten - Research publications by members of the University of Glasgow http://eprints.gla.ac.uk 


\section{THE METAPHYSICAL CASE FOR LUCK EGALITARIANISM*}

\section{INTRODUCTION}

Over the past quarter of a century so-called "luck egalitarianism" has taken centre stage in discussions of distributive justice. ${ }^{1}$ Its generic distributive principle, equality of opportunity for advantage, states that variations in the levels of advantage held by different persons (i.e. inequalities) are permitted by justice if and only if those persons are responsible for those (or equivalent) variations. ${ }^{2}$ On this principle disadvantages that arise from congenital disability, poor native endowment of talent, and birth into unfavorable social or economic circumstance are typically said to give rise to entitlements for compensation, for they derive from inequalities of opportunity, whereas those that arise from choices to make more or less effort, or to pursue some goals rather than others, do not, for they reflect different uses of opportunity.

In recent years luck egalitarianism has come into disrepute in some quarters. This is in part attributable to the array of (purportedly) compelling counterexamples and rival theories that it, as a major account of distributive justice, was bound to provoke. ${ }^{3}$ Unusually, however, metaphysical considerations have informed much of the negative reassessment. ${ }^{4}$ Particularly damaging, if correct, is the claim that luck egalitarianism is committed to metaphysical libertarianism - the view that free human action is possible - despite reasonable doubts over that doctrine's truth. Why, it may be asked, deny assistance to "the lazy" or "the reckless" if they may be,

\footnotetext{
* This article was published as Carl Knight, "The Metaphysical Case for Luck Egalitarianism," Social Theory and Practice, 32 (2006), 173-189. Published by Florida State University Department of Philosophy. https://www.jstor.org/stable/23562083
} 
metaphysically speaking, just as non-responsible for their disadvantages as the congenitally disabled and naturally untalented are for theirs?

I will argue that luck egalitarianism may be plausibly construed as sensitive to metaphysically-based concerns such as these. In section II I argue that the "libertarian assumption" allegation itself rests upon the assumption that luck egalitarians are committed to rewarding certain kinds of actions regardless of whether or not those who perform them are actually responsible for performing them. But this assumption is at odds with the reference to responsibility that is at the heart of luck egalitarianism. It follows that luck egalitarianism would not be undermined were it actually the case that both metaphysical libertarianism (or libertarianism for short) and compatibilism were false. If the lazy or reckless are not actually responsible for their disadvantages then luck egalitarianism will not, in principle, penalize them. In this regard luck egalitarianism is better positioned than outcome egalitarianism, which must assume, in precisely the sense intended by luck egalitarianism's critics, hard determinism or an equivalent position.

The critics attempt to strengthen their hand by suggesting that luck egalitarianism does not sit well with compatibilism. My response, given in section III, is firstly, that it has not been shown that there are any relevant differences in the moral implications of these two metaphysical theories, and secondly, that even if there were such differences, luck egalitarianism would be able to accommodate them by modifying its prescriptions.

The defense of luck egalitarianism of sections II and III invites the further objection that luck egalitarianism is, in the inevitable absence of a resolution of the free will problem, practically impotent. If luck egalitarians cannot know whether those who appear to be responsible for their disadvantages are really responsible for 
them, then they cannot know whether to compensate them. I meet this criticism in section IV with the proposal that a luck egalitarian government ought to distribute advantage on the basis of an educated guess about the metaphysics of responsibility. I suggest that a committee of specialists might be well qualified to make such a guess.

The overall argument is that reference to metaphysics shows that luck egalitarianism is at an advantage relative to outcome egalitarianism (and related positions), being superior in its account of responsibility and equal in the practical applicability of that account. This is not necessarily to say that luck egalitarianism ought to be favored over other accounts of equality (including outcome egalitarianism). Such accounts may be buttressed by moral objections to luck egalitarianism that do not appeal to metaphysics. But the argument does indicate that luck egalitarianism is, in the relevant respects, far better placed than is often supposed.

\section{THE CASE}

A general worry of critics of luck egalitarianism is that, in bringing choice and responsibility to centre stage in political philosophy, it entered treacherous waters. Specifically, it opened itself up to the libertarian assumption objection. Samuel Scheffler writes that "luck egalitarianism invites the objection that, like the political philosophies of the anti-egalitarian right, it tacitly derives much of its appeal from an implausible understanding of the metaphysical status of choice." ${ }^{5}$ Luck egalitarianism interprets all voluntary choices as exercises of responsibility, but such a relationship can only possibly hold if free will is possible; that is, if libertarianism is correct. ${ }^{6}$ As Saul Smilansky notes, from a hard determinist perspective, “[G. A.] Cohen's idea that there can be the sort of non-arbitrary 'genuine choice' which could justify some inequality would be simply seen as mistaken." These remarks, together with the 
notorious intractability of the free will problem, suggest that luck egalitarianism assumes an undoubtedly controversial (and according to some implausible) metaphysical theory.

I will not attempt to give any kind of full exploration of the free will problem here. But exploration of the relationship between metaphysics, justice and luck egalitarianism does, I hope to show, suggest that the latter is well positioned. Consider, then, five preliminary comments on the suggestion of the previous paragraph. Note first that the critic of luck egalitarianism must, in the case of luck egalitarianism at least, view the findings of philosophy as trumping widely held views about the social and political organization of society. The free will problem is not, it can safely be assumed, at the forefront of most persons' thoughts about justice. With this the consistency of certain combinations of anti-luck egalitarian arguments is threatened.

Take, for instance, the position that luck egalitarianism is undermined by both its suspect metaphysics and its divergence with commonplace moral judgments. Regarding luck egalitarianism's insistence that inequalities in the presence of a history of equivalent exercises of responsibility are morally wrong, but that differential responsibility-based inequalities are not, Scheffler writes that "[i]t is far from clear that, in this generalized form, this claim enjoys widespread intuitive support. The more common or intuitive view, I believe, is that the fairness or unfairness of differences in advantage resulting from, on the one hand, factors beyond people's control and, on the other, people's voluntary choices, is highly dependent on the prevailing social context and institutional setting." ${ }^{\text {I }}$ maintain that the claim that luck egalitarianism fails to coincide with 'the social and political conception of equality' is both more open to doubt than Scheffler acknowledges and of questionable normative importance. But even were it valid and morally weighty (I offer no 
arguments to the contrary here) it undercuts and is undercut by the metaphysical argument that Scheffler presents alongside it. If one allows that an account of distributive justice may be disproved on the ground of the weakness of its metaphysics, one surely ought to grant that the wholly metaphysically ignorant 'more common or intuitive view' is likely to be undermined in this way. Conversely, if one believes that the test of a political theory is the popularity of its prescriptions, one ought to view the distinctly ivory tower issue of the metaphysical credentials of such a theory as immaterial.

The second point, which has more importance for the main argument, concerns the precise sense in which luck egalitarianism is said to assume libertarianism. There is surely no conceptual need for a luck egalitarian to premise her theory on this (or any other) metaphysical theory. What difficulty is there in her saying "I know that you are not really responsible for this outcome, for hard determinism is true; but you certainly look responsible for it, so I'm going to hold you responsible for it"? The difficulty, surely, is a normative one, and so too, I take it, is the assumption - that is, luck egalitarianism looks far more plausible if it rewards and penalizes in a manner that is genuinely (i.e. according to the correct metaphysical theory) responsibility-sensitive, rather than in an arbitrary manner that is superficially responsibility-sensitive. The assumption, then, is metaphysical in character but morally motivated.

The final three points can be stated more briefly. The first is that libertarianism is not obviously wrong. Some political philosophers are happy to assert that libertarianism seems implausible to them without so much as an argument to that effect. ${ }^{9}$ But this is not an uncontroversial conclusion among metaphysicians; far from it. ${ }^{10}$ The next point is that, further objections (such as the unfairness of compatibilism- 
based inequality objection addressed in the next section) notwithstanding, luck egalitarianism only assumes (in the sense just described) either metaphysical libertarianism or compatibilism. Some luck egalitarians, indeed, think the second of those options the more promising. ${ }^{11}$ The final preliminary is that the libertarian assumption objection does itself rely upon the credibility of a certain controversial metaphysical theory - hard determinism. ${ }^{12}$ Theories of justice that do not give choice a central role are likely to be undercut, and luck egalitarianism appear preferable, if libertarianism or compatibilism are shown to be correct. There will, at least, be no metaphysical grounds for objecting to luck egalitarianism.

With these points the ground has been prepared for the luck egalitarian's central argument, the metaphysical uncertainty argument. She begins by observing that the best construal of luck egalitarianism understands luck thinly with regard to responsibility, i.e. as its inverse. ${ }^{13} \mathrm{I}$ am unlucky in this sense if I suffer from a disadvantage for which I am not responsible. Thick luck, by contrast, comes in many varieties, each of which has certain substantive content. Conceptions of thick luck will often fail to coincide with thin luck as their content is "more specific than the negation of our bottom line judgments about responsibility." 14 For instance, I am only unlucky in the particular thick sense of lack of regressive control of causes if I can or could control all the causes of my disadvantage, and all the causes of those causes. ${ }^{15}$ Suppose that I had control over the causes of my disadvantage, but not over their causes. If responsibility requires only non-regressive control then I am unlucky in this particular thick sense, but I am not unlucky in the thin sense. Those who have been described as luck egalitarians often use luck thickly, most often when referring to brute luck and option luck, which place the focus on the presence or absence of choice. ${ }^{16}$ But the use of thin luck is no departure from the core ideas of luck 
egalitarianism - most luck egalitarian works explicitly specify that it is the presence or absence of responsibility that is pivotal. ${ }^{17}$

Note that the focus on thin luck means there are as many different luck egalitarianisms as there are ways of defining free will and responsibility (and hence luck). The most obvious divide is between libertarian and compatibilist views, but neither of these groups is homogenous: on the one hand there are non-causal, eventcausal and agent-causal accounts, on the other there are multiple viewpoints, mesh, reasons-responsive and Strawsonian accounts. There are of course other accounts, and subdivisions within these accounts. ${ }^{18}$ But luck egalitarianism itself is not committed to either libertarianism or compatibilism, far less any particular formulation of free will and responsibility. It simply favors that account which is correct, or most correct.

If this is all granted, then even in the metaphysical worst-case scenario that hard determinism is true, luck egalitarianism would be in no worse a state in the relevant regards than other forms of egalitarian justice. If hard determinism is assumed then the luck egalitarian principle of equality of opportunity for advantage is in all possible circumstances equivalent to the outcome egalitarian principle of equality of advantage. If no one is responsible for any of their preferences, equality of opportunity for advantage's policy of compensating for those and only those disadvantages for which persons are not responsible amounts to equality of advantage's policy of compensating for all disadvantages. ${ }^{19}$

This should be a familiar point. ${ }^{20}$ Yet it casts doubt on Scheffler's claim that "the appeal of luck egalitarianism may seem tacitly to depend on a form of metaphysical libertarianism." 21 Without libertarianism, and even without compatibilism as well, luck egalitarianism's metaphysics-based appeal is equal to that of its main rival. Furthermore, the metaphysical uncertainty argument naturally 
pushes to a stronger conclusion. Given our actual and inevitable uncertainty over which answer to the free will problem is correct, luck egalitarianism is at a prima facie advantage over outcome egalitarianism, whose categorical insensitivity to responsibility is either equivalent to luck egalitarianism's sensitivity (if hard determinism is true) or prima facie counterintuitive (if libertarianism or compatibilism are true). Outcome egalitarianism would be subject to the counterpart of the libertarian assumption objection - the hard determinist assumption objection - with no possibility of recourse to a metaphysical uncertainty argument, for metaphysical certainty is assumed. Of course, the metaphysics-based moral counterintuitiveness may be overcome by some independent normative argument to the effect that responsibility for one's disadvantage should not preclude compensation for that disadvantage. ${ }^{22}$ But clearly no such argument is available from metaphysics - indeed, as I said, some arguments of this type may be not be available to the metaphysically disposed. Engagement with the free will problem leads us to what is, if anything, an embarrassing conclusion for luck egalitarianism's critics, and an emboldening one for its advocates.

\section{COMPATIBILISM}

So far I have treated compatibilism and libertarianism as though, so far as distributive justice is concerned, they were equivalent. Some may suspect that it is precisely this conflation that has powered my argument, for the critics claim that the two theories are not equally welcome to luck egalitarians. Scheffler notes that, according to libertarianism, "genuinely voluntary choices belong to a different metaphysical category than do other causal factors. If the distinction between choices and unchosen circumstances is viewed as a fundamental metaphysical distinction, then it may seem 
capable of bearing the enormous political and moral weight that luck egalitarianism places on it." ${ }^{23}$ Compatibilism is less conducive to luck egalitarianism as, "[i]n the absence of such a conception [of the metaphysical status of genuine choice], it is simply not clear why choice should matter so much: why such fateful political and economic consequences should turn on the presence or absence of genuine choice."24 The idea here appears to that, while it is true that agents may have attributive responsibility for their actions if compatibilism is correct, those grounds for moral appraisal do not justify the particular substantive responsibility judgments made by luck egalitarians. ${ }^{25}$ In other words, fully responsibility-sensitive distribution is inappropriate where the (attributive) responsibility in question is merely compatibilist. This is the unfairness of compatibilism-based inequality objection.

But why exactly does the particular way in which choices are genuine matter to luck egalitarians? Why is one type of attributive responsibility a more plausible basis for distribution? Without answers to these questions the objection is little more than the assertion that compatibilism just is not enough for the luck egalitarian's purposes.

Scheffler attempts to answer these questions by linking compatibilism and luck egalitarian unfairness. He starts by noting that, according to compatibilists, "the relation of choice to the agent's values, deliberations, and preferences will make the presence or absence of choice an important factor in many contexts. Still, it will be only one factor among others, and its relative importance will vary depending on the context." ${ }^{26}$ Scheffler believes that the status of choice in a compatibilist scheme creates particular problems for the luck egalitarian: 
[A] talent for choosing wisely is just one human skill among others. What we call practical wisdom is affected in complex ways by other traits of character and temperament, and is not itself distributed equally among people. ... Nor can luck egalitarians say that the choices made by those who are less skilful choosers are for that reason alone less genuine choices, for luck egalitarians hold that, if there are genuine choices, then people may reap the rewards of the good ones and must bear the costs of the foolish ones. ${ }^{27}$

The claim, then, is that the luck egalitarian's willingness to punish those who choose badly seems especially harsh when combined with a compatibilist account of responsibility, as those choices do not themselves belong to any special metaphysical category, and are affected by each individual's practical reasoning capability, which varies from one individual to another. Clearly, a particular account of responsibility is assumed here. But even if we were to allow that, the argument is misconceived. A poor choice-making capability is a disadvantage just like any other for the luck egalitarian if it may result in a loss in advantage, as is the case here. As such it will give rise to compensation unless the individual is responsible for it. ${ }^{28}$ Scheffler does not state whether, in the kind of cases he has in mind, the "less skilful choosers" are responsible for their lack of skill. But if they are responsible for it there is nothing obviously wrong with penalizing them for that, just as it is may be appropriate to compensate them where they are not responsible. ${ }^{29}$

Marc Fleurbaey has this to say in support of the unfairness of compatibilismbased inequality objection: 
Even if a compatibilist account may provide grounds for moral attitudes of praise or dispraise, it is more questionable whether it could justify differences of welfare or advantage between people. The presence of an identified deterministic factor explaining a person's behavior gives her very good arguments for complaining about any penalty in welfare or advantage imposed by equal opportunity institutions, or symmetrically, seriously undermines any claim to preferential treatment yielding a higher outcome. In brief, the equal opportunity approach faces a sort of dilemma: its ethical appeal is stronger with an incompatibilist view of free will than with a compatibilist one, but the doubt problem is then also more acute. ${ }^{30}$

Here the focus is on the kinds of judgments of substantive responsibility that are appropriate given compatibilism. While Scheffler's argument might suggest that attributive responsibility in such metaphysical circumstances has no substantive significance, Fleurbaey's accepts that it might, but just not in the way that luck egalitarians imagine.

Were Fleurbaey's person's “very good arguments for complaining about any penalty in welfare or advantage ..." actually to materialize independently of the outright rejection of compatibilism - i.e. if it was accepted that the negligent were not, on the grounds of responsibility, to be disadvantaged, but were nevertheless an appropriate object of (non-disadvantaging) dispraise - that would suggest that theories of justice should distinguish between compatibilism and libertarianism in a way that I have not up to now considered. But there are two good reasons for thinking that this need not worry the luck egalitarian. First, it does not seem obvious to me that any such arguments will emerge. We usually want to back up a justified expression of 
praise or dispraise with action of some kind. It seems wholly inadequate to respond to grossly irresponsible or even malicious behavior with a mere shake of the head. We cannot, for instance, tolerate "moral hostage taking" by those who know that an egalitarian society will pay for their destructive or extravagant behavior. ${ }^{31}$ Assuming that such persons are, determinism notwithstanding, responsible for their behavior, it may well strike us as wrong to subsidize their reprehensible choices. Less drastic irresponsibility is typically met with correspondingly less drastic, though still significant, sanctions.

Second, if my hunch is mistaken, and some substantial compatibilism-based inequalities can be shown to be unfair, the relevance of compatibilist attributive responsibility to distributive justice would have been diminished. But luck egalitarianism would remain an attractive position as long as libertarianism is viable and/or some compatibilism-based inequalities are fair. Even if these were not possibilities luck egalitarianism would fare no worse than outcome egalitarianism as its judgments of substantive responsibility would reflect this state of affairs. In other words, the conclusion need only be that luck egalitarianism should not treat any positive result regarding the truth of compatibilism, however limited its moral implications, as though it justified fully responsibility-sensitive distributive measures. This can be accommodated readily enough.

\section{APPLICATION}

It appears that luck egalitarianism is a coherent and distinct distributive theory on the assumption of either libertarianism or compatibilism, although the latter may place limits on the degree of responsibility-sensitivity that is appropriate. If hard determinism is assumed luck egalitarianism remains coherent, although in that case it 
is much harder to distinguish it from outcome egalitarianism. We are left, however, with the question of what a government (or other distributive body) ought to do in the real world, where we can make no such assumptions. Outcome egalitarians have an easy answer: distribute advantage equally. ${ }^{32}$ "Non-metaphysical" luck egalitarians might recommend that we reward and penalize wherever certain criteria for responsibility are satisfied, regardless of whether metaphysically genuine responsibility has actually been exercised. ${ }^{33}$ But such a position falls squarely in the sights of the libertarian assumption objection - it rewards or penalizes where there is the mere veneer of responsibility. Alternatively, if luck egalitarians insist that distribution only occurs where the presence of genuine responsibility is beyond dispute they will have to wait for the free will problem to be resolved, in which case the uncertainty that is the source of their metaphysical strength invites fatal criticism at the level of application. As Fleurbaey comments, "egalitarianism would be seriously endangered of being practically impotent if it was held hostage by metaphysics." ${ }^{34}$ Can luck egalitarians take metaphysics seriously, as I have urged they should, and still offer concrete distributive proposals? I believe they can, provided they accept the pragmatic solution of legislating on the basis of our best metaphysical guess. I will describe how this might be done in probabilistic terms, but other methods are equally compatible with luck egalitarianism.

Imagine a society consisting of $\mathrm{A}$ and $\mathrm{B}$, who each hold fifteen units of advantage, and $\mathrm{C}$, who holds sixty-nine units of advantage. A is, doubts about free will aside, fully responsible for his disadvantage relative to $\mathrm{C}$; it has arisen, say, from decisions that he made but that $\mathrm{C}$ declined. $\mathrm{B}$, however, is not responsible for her disadvantage; her actions are equivalent to those of $\mathrm{C}$. ( $\mathrm{C}$ is therefore responsible for his advantage over A but not responsible for his advantage over B.) Let us assume 
that we cannot increase or decrease the number of units in the society; redistribution is the only means of redressing the inequalities we find there. In the first scenario hard determinism is correct, and equality of opportunity for advantage recommends, with equality of advantage, that thirty-six units be extracted from $\mathrm{C}$ and the product distributed equally between $\mathrm{A}$ and $\mathrm{B}$, leaving each person with thirty-three units. In the second scenario libertarianism or (full, distribution-relevant) compatibilism are correct, and equality of opportunity for advantage recommends that twenty-seven units be extracted from $\mathrm{C}$ and the entire product handed to $\mathrm{B}$, leaving $\mathrm{B}$ and $\mathrm{C}$ with forty-two units and A with the 15 units with which he began.

The problem, as I said, is that we do not know whether hard determinism, libertarianism or compatibilism are true. But what is our best guess? If we had no reasons for or against these theories we might do best to invoke the principle of insufficient reason, and treat each theory as though it were equally likely to be correct. ${ }^{35}$ In that case, if we restrict our attention to the three theories (including compatibilism only in its full sense and excluding any of the recent revisionist theories), the distribution is defined by both the first two scenarios, though the weight of the second is double that of the first (as two of the three theories recommend the second). Equality of opportunity for advantage would on that basis recommend that thirty units be extracted from $\mathrm{C}$, with the product divided unevenly between A and B, leaving A with twenty-one units, and $\mathrm{B}$ and $\mathrm{C}$ with thirty-nine units each.

It is generally supposed, however, that we do have reasons, albeit radically inconclusive ones, for and against metaphysical theories. For this reason the principle of insufficient reason is inapplicable. Nevertheless, a probabilistic approach appears to be reasonable. Governments have various ways of arriving at educated guesses; luck egalitarianism has no preference here, other than favoring greater accuracy over 
lesser accuracy. I will describe one option here: a responsibility committee composed of some of the leading authorities on the relevant metaphysical issues. The committee would be representative in terms of the positions (hard determinism, libertarianism, etc.) initially held by each member, though they may change during the course of the committee's deliberations. It would be charged with surveying the research appropriate to its topic and would ultimately provide the distributive arm of the government with their assessments of the likelihoods of each of the two scenarios, and any variations (such as ones involving the minimal, non-distribution-relevant compatibilism suggested by the unfairness of compatibilism-based inequality objection), being correct. It would be a simple task then to establish the appropriate distributive regime. For example, if the specialists decide that the first scenario (or some equivalent involving minimal compatibilism) is twice as likely to be true as the second, equality of opportunity for advantage would recommend that thirty-three units be extracted from $\mathrm{C}$, with the product divided unevenly between $\mathrm{A}$ and $\mathrm{B}$, leaving A with twenty-seven units, and $\mathrm{B}$ and $\mathrm{C}$ with thirty-six units each.

I am confident that there is no consensus among the leading metaphysicians in developed Anglophone countries that either hard determinism or outright libertarianism/compatibilism is correct. I am also confident that there is no reason to believe that such a consensus would arise from the committee's deliberations. On these grounds I speculate that the committees of these countries would settle on compromises that give some weight to both hard determinism and libertarianism/compatibilism. ${ }^{36}$ The distributions mentioned in the two preceding paragraphs are embodiments of such compromises. ${ }^{37}$ In practice luck egalitarians will give some weight to equalizing both opportunities and outcomes. Thus the typical luck egalitarian compensation pattern mentioned in the introduction - compensation 
for disadvantages arising from congenital disability, poor native endowment of talent, and birth into unfavorable social or economic circumstance, but no compensation for disadvantages arising from choices to make more or less effort, or to pursue some goals rather than others - receives a qualified endorsement, the main divergence being that there will be some (though less than full) compensation for disadvantages apparently arising from choices. Other ways of arriving at a decision (including Roemer's method mentioned below) are, for parallel reasons of demography, likely to have a similar outcome.

Imperfect as the committee of specialists approach may be, I think it is reasonable enough method. Our best guess is that metaphysicians are the group best qualified to make the required decision. We could, at any rate, do worse. Consider John Roemer's contrasting view. He puts forward an "algorithm by which any society, with its particular views concerning the extent to which persons can overcome their circumstances by acts of will, can implement an egalitarianism of opportunity consonant with those views. In this sense, my proposal is political and not metaphysical." ${ }^{38}$ Such an approach treats society as a whole as the appropriate decision-making body. But this group is severely under-qualified. The vast majority of the population will begin with no or virtually no philosophical expertise. Public debate may be all but worthless, for proponents of rival views may find that logical argumentation is a less effective way of persuading others than rhetoric and emotional appeal. ${ }^{39} \mathrm{We}$ want members of the decision-making body to make judgments about the truth rather than merely express their preferences. We are less likely to get this as the body gets larger and less familiar with the topic. Many members if the public may be motivated by unreflective attitudes, stereotypes and self-interest. As Fleurbaey observes, Roemer's proposal is a "dangerous tool for wanton applications of biased 
ideologies. ... It would be just too easy if hard metaphysical issues could always properly be decided by politicians and voters." 40 We have no reason for thinking that the metaphysicians would actually fare worse than the general public's complete stab in the dark, and some reason for hoping that they would do better. ${ }^{41}$ In some spheres democracy may further luck egalitarian ends; in this one, however, it does not.

Perhaps it would be said that the committee would itself be ideological biased, or even deterministically driven. The second problem obviously runs very deep. But we have good reasons for wanting to arrive at an informed decision, and unfortunately there is no way of getting to one without running this epicycling risk. I also cannot say that the first problem would not arise, but I think it less serious in the case of the committee than that of most alternatives, given the knowledge and ability of the members, and the time set aside for consideration and discussion of the relevant problems. They ought also to be less prone to being moved by self-interest. ${ }^{42}$ Short of randomly assigning probabilities to the two scenarios we can never be sure to have eradicated the threat of ideological bias. Certainly, any political philosopher who simply assumes her favored metaphysical theory is being anything but ideologically neutral. If there is a fully neutral method then luck egalitarianism is open to it; if there is not then the committee will suffice.

\section{CONCLUDING REMARKS}

Cohen famously acknowledged the anxiety "that to make choice central to distributive justice lands political philosophy in the morass of the free will problem." He "unreassuringly" replied that "we may indeed be up to our necks in the free will problem, but that is just tough luck. It is not a reason for not following the argument where it goes. ${ }^{\prime 3}$ On one reading the implication of this appears to be that before 
responsibility-sensitive justice came along political philosophers did not have to worry about metaphysics. ${ }^{44}$ Such a view grants too much ground to the critic. If hard determinism is correct, outcome egalitarianism appears to be the obvious option for metaphysically-minded egalitarians. (I have noted that this scenario does not, in point of fact, undermine luck egalitarianism, but that would hardly be worth arguing for were there never to be any dispute over practical recommendations.) But for political philosophy to assume that this is the case is for the field to have its head in the sand. If libertarianism or compatibilism are true the attractions of outcome egalitarianism are far less obvious. Given our actual metaphysical uncertainty it is quite reasonable to ask how responsibility might be accommodated by a theory of equality, if only to test how equality of advantage fares against such a theory. If luck egalitarianism did not exist, it would have to be invented. For the reasons suggested above, those egalitarians who take metaphysics seriously should be amazed that we ever did without it. ${ }^{45}$

\section{NOTES}

\footnotetext{
${ }^{1}$ The luck egalitarian era was precipitated by the publication of Ronald Dworkin's "What Is Equality? Part One: Equality of Welfare. Part Two: Equality of Resources," Philosophy \& Public Affairs 9-10 (1981): 185-246, 283-345. Elizabeth Anderson introduced the phrase "luck egalitarianism" in "What Is the Point of Equality?" Ethics 109 (1999): 287-337. Dworkin himself explicitly rejects the luck egalitarian tag. See Ronald Dworkin, “Equality, Luck and Hierarchy,” Philosophy \& Public Affairs 31 (2003): 190-8; cf. Samuel Scheffler, "Equality as the Virtue of Sovereigns: A Reply to Ronald Dworkin," Philosophy and Public Affairs 31 (2003): 199-206, at p. 200. Whatever the correct interpretation of Dworkin's work may be, its influence on luck egalitarians is not in doubt.

2 "Advantage" is used here as a placeholder for whatever good it is that distributive justice is in the business of distributing. G. A. Cohen has proposed a composite of welfare and (objective) resources (what he calls "equal access to advantage") while another prominent luck egalitarian, Richard Arneson,
} 
has proposed welfare (hence "equality of opportunity for welfare"). See Cohen, "On the Currency of Egalitarian Justice," Ethics 99 (1989): 906-44; Arneson, "Equality and Equal Opportunity for Welfare," Philosophical Studies 56 (1989): 77-93; and "Liberalism, Distributive Subjectivism, and Equal Opportunity for Welfare," Philosophy and Public Affairs 19 (1990): 159-94.

${ }^{3}$ See Anderson; Marc Fleurbaey, "Equal Opportunity or Equal Social Outcome?" Economics and Philosophy 11 (1995): 25-55; Jonathan Wolff, "Fairness, Respect, and the Egalitarian Ethos," Philosophy and Public Affairs 27 (1998): 97-122; Seana Valentine Shiffrin, "Paternalism, Unconscionability, and Accommodation,” Philosophy and Public Affairs 29 (2000): 206-50; Timothy Hinton, "Must Egalitarians Choose Between Fairness and Respect?" Philosophy and Public Affairs 30 (2001): 72-87; Samuel Scheffler, “What is Egalitarianism?” Philosophy and Public Affairs 31 (2003): 5-39; "Choice, Circumstance and the Value of Equality," Politics, Philosophy and Economics 4 (2005): 5-28; and Anne Philips, “Defending Equality of Outcome,” Journal of Political Philosophy 12 (2004): $1-19$.

${ }^{4}$ See Marc Fleurbaey, "Equal Opportunity or Equal Social Outcome?"; "Egalitarian Opportunities," Law and Philosophy 20 (2001): 499-530; Scheffler, "What is Egalitarianism?”; “Choice, Circumstance and the Value of Equality"; Saul Smilansky, "Egalitarian Justice and the Importance of the Free Will Problem," Philosophia 25 (1997): 153-161; Mathias Risse, "What Equality of Opportunity Could Not Be," Ethics 112 (2002): 720-47; Matt Matravers, “Responsibility, Luck, and the 'Equality of What?' Debate," Political Studies 50 (2002): 558-72; and S. L. Hurley, Justice, Luck, and Knowledge (Cambridge, MA: Harvard University Press, 2003).

${ }^{5}$ Scheffler, "What Is Egalitarianism?” p. 18. See also Matravers, p. 560.

${ }^{6}$ In one place Scheffler says that "[s]ome luck-egalitarian writings seem implicitly to suggest" this relationship (Scheffler, "What Is Egalitarianism," pp. 17-8). But he clearly does not take himself to be merely drawing attention to the misleading signals of particular luck egalitarians. Earlier in the same paragraph he asserts that "the degree of weight that the luck egalitarian places on the distinction between choices and circumstances seems, on its face, to be ... philosophically dubious." Given this, and the general current of his work, it is reasonable to assume that Scheffler believes that luck egalitarianism is morally reliant upon libertarianism.

${ }^{7}$ Smilansky, p. 156. 
${ }^{8}$ Scheffler, "What Is Egalitarianism?" pp. 32-3, footnote suppressed. See also Scheffler, "Choice, Circumstance and the Value of Equality," pp. 9-10.

${ }^{9}$ Scheffler, "What Is Egalitarianism?" pp. 17-8; "Choice, Circumstance and the Value of Equality" p. 13.

${ }^{10}$ See note 37 below.

${ }^{11}$ Eric Rakowski, Equal Justice (Oxford: Oxford University Press, 1991), pp. 76-7, 113-5; John Roemer, "Defending Equality of Opportunity," The Monist 86 (2003): 261-82, at p. 262. Mathias Risse maintains that the argument of Roemer's book Equality of Opportunity assumes the impossibility that both libertarianism and compatibilism are correct. See John Roemer, Equality of Opportunity (Cambridge, MA: Harvard University Press, 1998). However, whatever the validity of this criticism, Risse states that it is inapplicable to the theories of Cohen, Dworkin and Arneson (Risse, p. 743 n. 40).

${ }^{12}$ If the unfairness of compatibilism-based inequality objection could be upheld, the libertarian assumption objection would rely upon either hard determinism or compatibilism being correct.

${ }^{13} \mathrm{~S}$. L. Hurley states that "[w]hat is a matter of thin luck for [an] agent is just what he is not responsible for, and what he is responsible for is not a matter of thin luck for him" ("Luck, Responsibility, and the Natural Lottery,” Journal of Political Philosophy 10 [2002]: 79-94, at pp. 7980). A terminologically different but in effect identical strategy would be to replace the term "luck egalitarianism" with "responsibility-sensitive egalitarianism." A similar strategy is taken in some of Arneson's more recent papers, although the theory he now espouses ("responsibility-catering prioritarianism") is, strictly speaking, non-egalitarian. See Richard Arneson, "Luck Egalitarianism and Prioritarianism," Ethics 110 (2000): 339-49; "Egalitarian Justice versus the Right to Privacy," Social Philosophy and Policy 17 (2000): 91-119. I generally take the thin luck strategy, however, as the phrase "luck egalitarianism" appears to be entrenched.

${ }^{14}$ Hurley, "Luck, Responsibility, and the Natural Lottery," pp. 80.

${ }^{15}$ See Hurley, "Luck, Responsibility, and the Natural Lottery," pp. 81-84.

${ }^{16}$ Dworkin, “What Is Equality,” pp. 293-5; Arneson, "Equality and Equal Opportunity for Welfare," pp. 83-4; "Liberalism, Distributive Subjectivism, and Equal Opportunity for Welfare," p. 176; Cohen, "On the Currency of Egalitarian Justice,” pp. 908, 916; Rakowski, pp. 74-5.

${ }^{17}$ Other criteria, such as control or (genuine) choice, are also often mentioned. See the texts cited in note 16 above. In such cases it is often assumed that control and choice coincide with responsibility. I 
think it evident that, were responsibility and such other factors to come into conflict, it would be the latter with which Arneson and Cohen would dispense. Larry Temkin also holds that egalitarian distributive justice is in part dependent upon "the mare's nest of free will" (Equality [Oxford: Oxford University Press, 1993], p. 18 n. 33). However, Roemer and Dworkin seem to disagree (see note 33 below).

${ }^{18}$ For good overviews of contemporary libertarianism and compatibilism see Randolph Clarke, “Incompatibilist (Nondeterministic) Theories of Free Will," The Stanford Encyclopedia of Philosophy (Fall 2004 Edition), ed. Edward N. Zalta, URL = $<$ http://plato.stanford.edu/archives/fall2004/entries/incompatibilism-theories/>; Michael McKenna, "Compatibilism," The Stanford Encyclopedia of Philosophy (Summer 2004 Edition), ed. Edward N. Zalta, URL $=<$ http://plato.stanford.edu/archives/sum2004/entries/compatibilism/.

${ }^{19}$ This is not, of course, to say that, on this assumption, equality of opportunity for advantage does itself reduce to equality of advantage. Even though the two principles' recommendations would be identical in even the most unusual circumstances, the justification for these recommendations would be different (see note 29 below).

${ }^{20}$ See Arneson, "Equality and Equal Opportunity for Welfare," p. 86, and G. A. Cohen, "Equality of What? On Welfare, Goods and Capabilities," in The Quality of Life, ed. Martha Nussbaum and Amartya Sen (Oxford: Oxford University Press, 1993), p. 28.

${ }^{21}$ Scheffler, “What Is Egalitarianism?” p. 19.

${ }^{22}$ For arguments of this type see the works cited above, note 3. For responses to some such arguments see Arneson, "Luck Egalitarianism and Prioritarianism"; "Egalitarian Justice versus the Right to Privacy”; and Carl Knight, "In Defence of Luck Egalitarianism,” Res Publica 11 (2005): 55-73.

${ }^{23}$ Scheffler, "Choice, Circumstance and the Value of Equality," p. 12.

${ }^{24}$ Scheffler, "Choice, Circumstance and the Value of Equality," p. 13.

${ }^{25}$ For the distinction between attributive and substantive responsibility see T. M. Scanlon, What We Owe to Each Other (Cambridge, MA: Harvard University Press, 1998), ch. 6.

${ }^{26}$ Scheffler, "Choice, Circumstance, and the Value of Equality," p. 13.

${ }^{27}$ Scheffler, "Choice, Circumstance, and the Value of Equality," p. 13.

${ }^{28}$ Scheffler suggests that the importance that Arneson attaches to choice is particularly questionable given his acknowledgment that some are better at making choices than others. See Scheffler, "Choice, 
Circumstance, and the Value of Equality," p. 26 n. 18; Richard Arneson, "Review of Sovereign Virtue," Ethics 112 (2002): 367-71, at p. 371; "Equality of Opportunity for Welfare Defended and Recanted," Journal of Political Philosophy 7 (1999): 488-97, at p. 496. But Arneson and other luck egalitarians explicitly state that interpersonal variations in ability to use options effectively should be taken into account. For example, those who act irresponsibly due to their upbringing would not be penalized for their irresponsibility. See Richard Arneson, "Egalitarianism and the Undeserving Poor," Journal of Political Philosophy, 5, 327-50, at p. 332; "Equality and Equal Opportunity for Welfare," pp. 85-6; Cohen, "On the Currency of Egalitarian Justice," pp. 916-7.

${ }^{29}$ A possible response to the argument of this paragraph is foreshadowed by Dworkin, who argues that no tastes are genuinely chosen as those that might appear to be are ultimately traceable to uncultivated second-order tastes. See Ronald Dworkin, Sovereign Virtue: The Theory and Practice of Equality (Cambridge, MA: Harvard University Press, 2000), ch. 7; "Replies," in Dworkin and His Critics, ed. Justine Burley (Oxford: Blackwell, 2004), pp. 346-7, 391 n. 22. Likewise, it might be claimed that no individual can really choose to develop or neglect their choice-making capability in the required way as any such choices will be influenced by their initial capability. These arguments raise questions that cannot be answered without going too far afield. Fortunately they do not need to be answered for our purposes as luck egalitarianism could, in any event, accommodate the arguments. Cohen's response to Dworkin's argument is, mutatis mutandis, equally applicable here: "[i]t is a matter of principle for equality of opportunity for welfare that tastes are compensated for only if and when and because they are (to put it crudely) not chosen, however often (including never) they are in fact chosen, and equality of welfare denies that principle. That deep difference of principle would survive even if it should turn out that all tastes are unchosen ..." ("Expensive Taste Rides Again," in Dworkin and His Critics, ed. Justine Burley [Oxford: Blackwell, 2004], p. 19, original emphasis). If luck egalitarianism refused to reward or penalize any choices then it obviously could not be subject to the charge that it disadvantaged less skilful choosers.

${ }^{30}$ Fleurbaey, "Equal Opportunity or Equal Social Outcome?" p. 40.

${ }^{31}$ See Simon Keller, "Expensive Tastes and Distributive Justice," Social Theory and Practice 28

(2002): 529-52; Dworkin, “What Is Equality?” pp. 228-240.

${ }^{32}$ A related position ensures outcome equality of some types of advantage or goods but not others. Typically, basic liberties fall in the former category whereas happiness falls in the latter; other goods, 
such as wealth, fall on different sides of the line according to different versions of the general position. Compare John Rawls, A Theory of Justice (Cambridge, MA: Harvard University Press, 1971); Fleurbaey "Equal Opportunity or Equal Social Outcome?"; Anderson; and Scheffler, "What Is Egalitarianism?" Insofar as a variant of this position ensures outcome equality it is susceptible to the hard determinist assumption objection. Insofar as it fails to equalize advantage its egalitarian credentials are undermined, although not for reasons that are relevant to the present argument.

${ }^{33}$ This is, I believe, Roemer's stance; see the discussion in the text. It also shares significant similarities with Dworkin's position. He insists, for instance, that resource distribution be option luck- and choicesensitive but brute luck- and circumstance-insensitive, with no requirement that the choices that give rise to option luck are metaphysically genuine; indeed, the relevance of the choice/circumstance distinction is based on the claim that it "tracks ordinary people's ethical experience" (Dworkin, Sovereign Virtue, pp. 289-90; see also p. 6).

${ }^{34}$ Marc Fleurbaey, “Egalitarian Opportunities," p. 502.

${ }^{35}$ The best-known discussion of the principle of insufficient reason in political philosophy is in Rawls, sec. 28. Rawls refuses to apply it, though on notoriously dubious grounds. See John C. Harsanyi, "Can the Maximin Principle Serve as a Basis for Morality? A Critique of John Rawls's Theory," American Political Science Review 64 (1975): 594-606.

${ }^{36}$ By "settle" I do not mean to imply that unanimous agreement is the necessary outcome of the committee's debates. We might assign each member of the committee equal power in setting its recommendation in the absence of unanimity. This is possible because the committee provides probability scores rather than policy documents. The committee could decide, say, that the first scenario is twice as likely to be true as the second either by unanimous agreement, or on the grounds that there are twice as many convinced hard determinists as there are libertarians and compatibilists combined, or on the grounds that this is the balance of power struck between those who hold a compromise position and those who take a hard line.

${ }^{37}$ Derk Pereboom reports that "the demographic profile of the free will debate reveals a majority of soft determinists" and "a minority" of libertarians; "[s]eldom has hard determinism ... been defended" (“Determinism al Dente," Nous 29 [1995]: 21-45, at p. 21). This suggests that there will be a compromise, but one strongly biased towards the libertarian/compatibilist viewpoint. 
${ }^{38}$ John Roemer, "A Pragmatic Theory of Responsibility for the Egalitarian Planner," Philosophy and Public Affairs 22 (1993): 146-66, at p. 149.

${ }^{39}$ See Jean Hampton, “Should Political Philosophy Be Done Without Metaphysics?” Ethics 99 (1989): 791-814, at p. 807 .

${ }^{40}$ Fleurbaey, "Egalitarian Opportunities," p. 503. See also Fleurbaey, "Equal Opportunity or Equal Social Outcome?" p. 39.

${ }^{41}$ Fleurbaey makes a different claim: “The problem with [Roemer's] political approach is that it is interesting only if society is indeed likely to decide correctly where responsibility lies" (Fleurbaey, "Egalitarian Opportunities," p. 503). In my view neither the committee nor society is actually likely to make the (metaphysically) correct decision. I maintain only that the former is likely to make a better (i.e. less wrong) decision than the latter.

${ }^{42}$ The danger of self-interest could be limited by exempting the members from the effects of their findings and placing them under the rule of certain pre-defined norms (such as those resulting from the previous committee's deliberations).

${ }^{43}$ Cohen, "On the Currency of Egalitarian Justice," p. 934.

${ }^{44}$ Though plausible, I do not believe that this is the correct reading. Scheffler seems to disagree, maintaining that Cohen is speaking as a luck egalitarian rather than as a political philosopher when he says "we may indeed be up to our necks," and interpreting Cohen's "tough luck" comment as ironic (Scheffler, “What Is Egalitarianism?” p. 18).

${ }^{45}$ I am grateful to Hillel Steiner, Peter Vallentyne, and an anonymous reviewer for their helpful remarks on earlier versions of this article. Research for the article was supported by the Arts and Humanities Research Council. 